\title{
Expression of $y$-H2AX Using Immunofluorescence Assay as an Adaptive Response of PBMC in Radiation Workers at Dharmais Cancer Hospital
}

\author{
Arifin Musthafa ${ }^{1}$, Fielda Djuita ${ }^{2}$, lin Kurnia ${ }^{3 *}$ \\ ${ }^{1}$ Department of Biomedical Science, Faculty of Medicine, University of Indonesia, Jakarta, Indonesia \\ ${ }^{2}$ Department of Radiotherapy, Dharmais Cancer Hospital, Jakarta, Indonesia \\ ${ }^{3}$ Division of Nuclear Medicine Technique and Radiation Biology, PTKMR-BATAN, Jakarta, Indonesia
}

\section{ARTICLE INFO}

\section{Article history:}

Received : 02 January 2018

Reviewed: 26 January 2018

Accepted : 29 August 2018

\section{Keywords:}

$\mathrm{Y}$-H2AX ;irradiation doses; PBMCs;

radiation worker

\begin{abstract}
A B STR A C T
Background: Exposure ionizing of radiation in radiation workers has the potential to cause DNA damage in the form of double strand break as the beginning of genomic instability. DNA damage can be observed with $\mathrm{\gamma}-\mathrm{H} 2 \mathrm{AX}$ as the biomarker of DNA double strand breaks (DSBs). The formation of $\mathrm{y}-\mathrm{H} 2 \mathrm{AX}$ in the nucleus can occur after radiation exposure of $1 \mathrm{mGy}$. This study aims to determine the radiation effects in radiation work environments as a study of adaptive responses of peripheral blood mononuclear cell (PBMCs) after radiation by observing $\mathrm{Y}-\mathrm{H} 2 \mathrm{AX}$ foci expression..
\end{abstract}

Methods: Blood samples from nine radiation workers and nine non-radiation workers were irradiated with doses $0 \mathrm{~Gy}, 1 \mathrm{~Gy}, 1.5 \mathrm{~Gy}$, and $2 \mathrm{~Gy}$. Detection of $\mathrm{\gamma}-\mathrm{H} 2 \mathrm{AX}$ foci was done by immunofluorescence assay. The mean of $\gamma-\mathrm{H} 2 \mathrm{AX}$ foci was counted in 50 PBMCs per sample. The comparison mean of $\mathrm{y}-\mathrm{H} 2 \mathrm{AX}$ foci was analyzed using $\mathrm{t}-$ independent test.

Result: Based on the result study, there were no significant differences in the number of $\gamma-\mathrm{H} 2 \mathrm{AX}$ foci without treatment $(p=0.807)$. The results of study showed that the formation of 2-3 foci per cell after exposure of $2 \mathrm{~Gy}$ increases along with the increasing irradiation doses.

Conclusion: The mean of index of $\gamma-\mathrm{H} 2 \mathrm{AX}$ foci in PBMCs within normal limits between non-radiation workers and radiation workers and level of risk DSBs damage is relatively similar after exposure at doses $1 \mathrm{~Gy}, 1.5 \mathrm{~Gy}$, and $2 \mathrm{~Gy}$.

\section{INTRODUCTION}

Biomarkers are tools to identify health risks from environmental influences such as radiation exposure, as an assessment of cancer risk and response to therapy. Therefore, it is necessary to evaluate the biomarkers occurring as a result of low dose ionizing radiation exposure and low dose rates including risk evaluation as a basic consideration for radiation protection standards $(1,2)$. lonizing radiation can cause damage to biological materials by ionizing or removing electrons to form positive ions and negative ions, and its power will decrease if the received energy becomes exhausted (3). lonizing radiation exposure to both low dose and high dose has the potential to cause deoxyribonucleic acid (DNA) damage in the form of double strand breaks (DSBs) or single strand break (SSB). The existence of lesions in DNA as the effect of ionizing radiation is the beginning of genomic instability that triggers cell death from radiation, cell transformation, and carcinogenesis $(4,5)$. Basically DNA damage can be studied using various observational methods such as $\mathrm{Y}-\mathrm{H} 2 \mathrm{AX}$ foci, chromosome aberration, micronucleus, and others (6).

Observation of the $\mathrm{Y}-\mathrm{H} 2 \mathrm{AX}$ foci was first found in DNA that was damaged by the ionizing radiation exposure. $\mathrm{Y}-\mathrm{H} 2 \mathrm{AX}$ is the nucleosome of the histone that acts to regulate the response to DNA damage and continues 
the activation of the repair signal. In this process, the occurrence of $\mathrm{\gamma}-\mathrm{H} 2 \mathrm{AX}$ phosphorylation around the DSB area formed the $\mathrm{Y}-\mathrm{H} 2 \mathrm{AX}$ foci. The formation of $\mathrm{\gamma}-\mathrm{H} 2 \mathrm{AX}$ in nucleus can occur after radiation exposure of $1 \mathrm{mGy}$ and the number increases along with the increasing dose (7-9). The occurrence of phosphorylation of the $\mathrm{H} 2 \mathrm{~A}$ histone variant $\mathrm{\gamma}-\mathrm{H} 2 \mathrm{AX}$ in serine 139 may be mediated by different protein kinases, including ataxiatelangiectasia mutated (ATM) and phosphatidylinositol 3-kinase (PI3K). After DSBs repair, there will be $\mathrm{y}-\mathrm{H} 2 \mathrm{AX}$ dephosporylation in serine 139 which can be done in the presence of wild type p53 and thus the foci $\gamma-\mathrm{H} 2 \mathrm{AX}$ cannot be seen in nucleus $(10,11)$.

This study aims to determine the radiation effects of radiation workers as an adaptive response study PBMCs (lymphocytes and monocytes) of radiation workers in Radiotherapy Installation Dharmais Cancer Hospital after radiation of $1 \mathrm{~Gy}, 1.5 \mathrm{~Gy}$, and $2 \mathrm{~Gy}$ by observing the expression of foci $\mathrm{Y}-\mathrm{H} 2 \mathrm{AX}$.

\section{MATERIAL AND METHOD}

\section{Sample}

Blood samples were obtained from nine radiation workers and nine non-radiation workers at the Dharmais Cancer Hospital, Jakarta. The Institutional Review Board at Medical Faculty of Indonesia had approved the study and all workers were provided informed consent before participating in this study (Number of Ethic Approval : 910/UN2.F1/ETIK/2017).

\section{Place and Time of Research}

Research activities were conducted in the cytogenetic and the molecular radiobiology laboratory, National Centre for Radiation Safety and Metrology Technology (PTKMR-BATAN), October-November 2017.

\section{Irradiation of Blood Samples}

For the treatment of irradiated samples prior to lymphocyte isolation, blood was irradiated with doses of $1 \mathrm{~Gy}, 1.5 \mathrm{~Gy}$, and $2 \mathrm{~Gy}$ with gamma rays produced by Cobalt-60 at the Centre for Applications of Radiation Isotopes (PAIR- BATAN). The Cobalt-60 plane is set at a rate of $60 \mathrm{~Gy} / \mathrm{hour}$.

\section{Detection of $\boldsymbol{Y}$-H2AX Foci}

Blood samples that were taken intravenously were isolated by standard procedures to obtain pure lymphocytes. The lymphocytes were dripped on the slide glass, fixed with $2 \%$ formaldehyde for 5 minutes, Triton-X $0.25 \%$ in PBS for 5 minutes, and with 1\% BSA solution in PBS for 5 minutes. We then added the first antibody $\mathrm{Y}-\mathrm{H} 2 \mathrm{AX}$ in $2 \%$ BSA for 15 minutes and added first antibody $(\gamma-\mathrm{H} 2 \mathrm{AX})$ for 45 minutes on the moist chamber and put in the incubator on 37.50C. Next was washing with $1 \% \mathrm{BSA}, 3 \times 15$ minutes, second antibody incubation for 30 minutes, PBS washing $3 \times 15$ minutes, drying wind and mounting. Detection of $\gamma-\mathrm{H} 2 \mathrm{AX}$ foci was done with 100x magnification fluorescent microscope. For $\mathrm{Y}-\mathrm{H} 2 \mathrm{AX}$ calculation, we calculated the average number of foci or $\gamma-H 2 A X$ foci group in 50 cells $(6,12)$.

\section{Data Analysis}

Data analysis to compare the mean index of $\mathrm{y}-\mathrm{H} 2 \mathrm{AX}$ foci was done by using SPSS ver 21. Hypothesis test with significance value is $p<0,05$. Kolmogorov-Smirnov test was used to ensure data normality. Relationship between foci $\mathrm{Y}-\mathrm{H} 2 \mathrm{Ax}$ and dose variation was analysed using T-independent test.

\section{RESULTS}

Microscopic observations were performed to see the $\mathrm{Y}-\mathrm{H} 2 \mathrm{AX}$ foci expressing a bright green on PBMCs (Figure 1). The formation of foci means DNA DSB damage occurred in PBMCs.
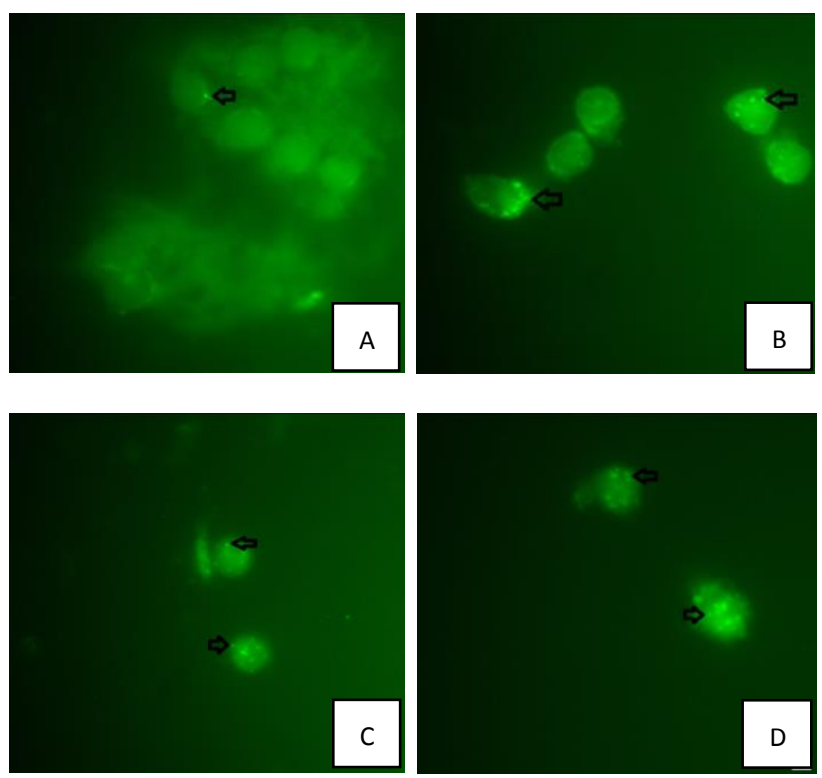

Figure 1. $\gamma-\mathrm{H} 2 \mathrm{AX}$ foci PBMCs radiation workers with irradiated dose (A) 0 Gy or without treatment, (B) $1 \mathrm{~Gy}$, (C) $1.5 \mathrm{~Gy}$, and (D) 2 Gy (100x magnification)

Morphological changes due to irradiation do not provide a different morphological image of either radiation with a dose of $1 \mathrm{~Gy}, 1.5 \mathrm{~Gy}$, or $2 \mathrm{~Gy}$. A round, large, and slightly formed nucleus that formed a hollow on one side was seen in the PBMCs. Cells also appear to colonize and accumulate in some parts.

Table 1, generally explains the increase of foci $\mathrm{p}-\mathrm{H} 2 \mathrm{AX}$ along with the increasing irradiated doses from $1 \mathrm{~Gy}$ to $2 \mathrm{~Gy}$ either in non-radiation workers or radiation workers. A low foci $\mathrm{Y}-\mathrm{H} 2 \mathrm{AX}$ indicates $\mathrm{H} 2 \mathrm{AX}$ in PBMCs are within normal limits and minimal DSB DNA damage, and the mean of $\mathrm{\gamma}-\mathrm{H} 2 \mathrm{AX}$ foci indicates high DSBs due to ionizing radiation. 
Table 1. Damage of DNA measured by histone $\mathrm{\gamma}-\mathrm{H} 2 \mathrm{AX}$ in PBMC radiation workers after irradiation 1-2 Gy using $\gamma$-rays

\begin{tabular}{|c|c|c|c|c|c|}
\hline Subject & $\begin{array}{l}\text { Tare Dose } \\
1 \text { Year } \\
\text { (mSv) }\end{array}$ & $0 \mathrm{~Gy}$ & $\begin{array}{l}1 \mathrm{~Gy} \\
60^{\prime}\end{array}$ & $\begin{array}{l}1.5 \mathrm{~Gy} \\
60^{\prime}\end{array}$ & $\begin{array}{l}2 \mathrm{~Gy} \\
60^{\prime}\end{array}$ \\
\hline \multicolumn{6}{|c|}{ Radiation Workers } \\
\hline A & 0.26 & 0.26 & 2.90 & 1.21 & 3.28 \\
\hline B & 0.00 & 0.14 & 1.08 & 1.68 & 1.72 \\
\hline C & 0.22 & 0.42 & 1.24 & 2.20 & 1.58 \\
\hline D & 0.18 & 0.16 & 1.98 & 1.76 & 1.96 \\
\hline $\mathrm{E}$ & 0.17 & 0.42 & 2.00 & 1.74 & 3.06 \\
\hline $\mathrm{F}$ & 0.06 & 0.72 & 1.78 & 2.26 & 2.52 \\
\hline G & 0.15 & 0.54 & 1.06 & 2.02 & 2.00 \\
\hline $\mathrm{H}$ & 0.17 & 0.42 & 2.76 & 2.94 & 3.40 \\
\hline Q & 0.75 & 0.16 & & & \\
\hline Average & 0.22 & 0.36 & 1.85 & 1.98 & 2.44 \\
\hline$\pm \mathrm{SD}$ & 0.21 & 0.20 & 0.71 & 0.51 & 0.73 \\
\hline \multicolumn{6}{|c|}{ Non-radiation Workers } \\
\hline I & 0.27 & 0.22 & 1.02 & 1.62 & 1.26 \\
\hline J & 0.00 & 0.26 & 1.22 & 1.40 & 1.70 \\
\hline K & 0.30 & 0.40 & 2.24 & 1.54 & 3.34 \\
\hline L & 0.00 & 0.28 & 1.46 & 2.64 & 1.82 \\
\hline M & 0.11 & 0.48 & 2.72 & 2.24 & 2.94 \\
\hline$N$ & 0.22 & 0.42 & & & \\
\hline 0 & 0.28 & 0.32 & 1.58 & 1.86 & 1.96 \\
\hline $\mathrm{P}$ & 0.28 & 0.40 & 0.86 & 1.22 & 2.10 \\
\hline $\mathrm{R}$ & 0.34 & 0.30 & 1.44 & 1.64 & 1.98 \\
\hline Average & 0.20 & 0.34 & 1.57 & 1.77 & 2.14 \\
\hline $\pm S D$ & 0.13 & 0.09 & 0.62 & 0.47 & 0.68 \\
\hline$p$ value & & 0.807 & 0.414 & 0.414 & 0.404 \\
\hline
\end{tabular}

The result of statistical analysis in Fig. 2 shows no significant difference in mean number of $\mathrm{y}-\mathrm{H} 2 \mathrm{AX}$ foci before radiation between non-radiation workers and radiation workers $(p=0.807)$. The difference in the distance of foci $\mathrm{Y}-\mathrm{H} 2 \mathrm{AX}$ in each sample occurs spontaneously or because of other factors affecting DSBs damage. At doses of $1 \mathrm{~Gy}$ to $2 \mathrm{~Gy}$, there was no significant difference in the mean number of $\mathrm{\gamma}-\mathrm{H} 2 \mathrm{AX}$ foci at doses of $1 \mathrm{~Gy}$ to $2 \mathrm{~Gy}$ with $\mathrm{p}$ values of 0.414 , 0.414 , and 0.404 , respectively. The difference in the distance of foci $\mathrm{Y}-\mathrm{H} 2 \mathrm{AX}$ in each sample occurs because of the differences in the biological response of each individual in receiving exposure to ionizing radiation resulting in DSBs damage.

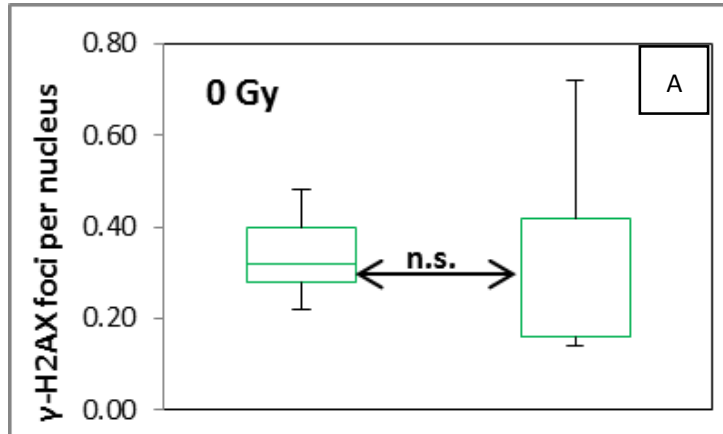

non radiation workers radiation workers
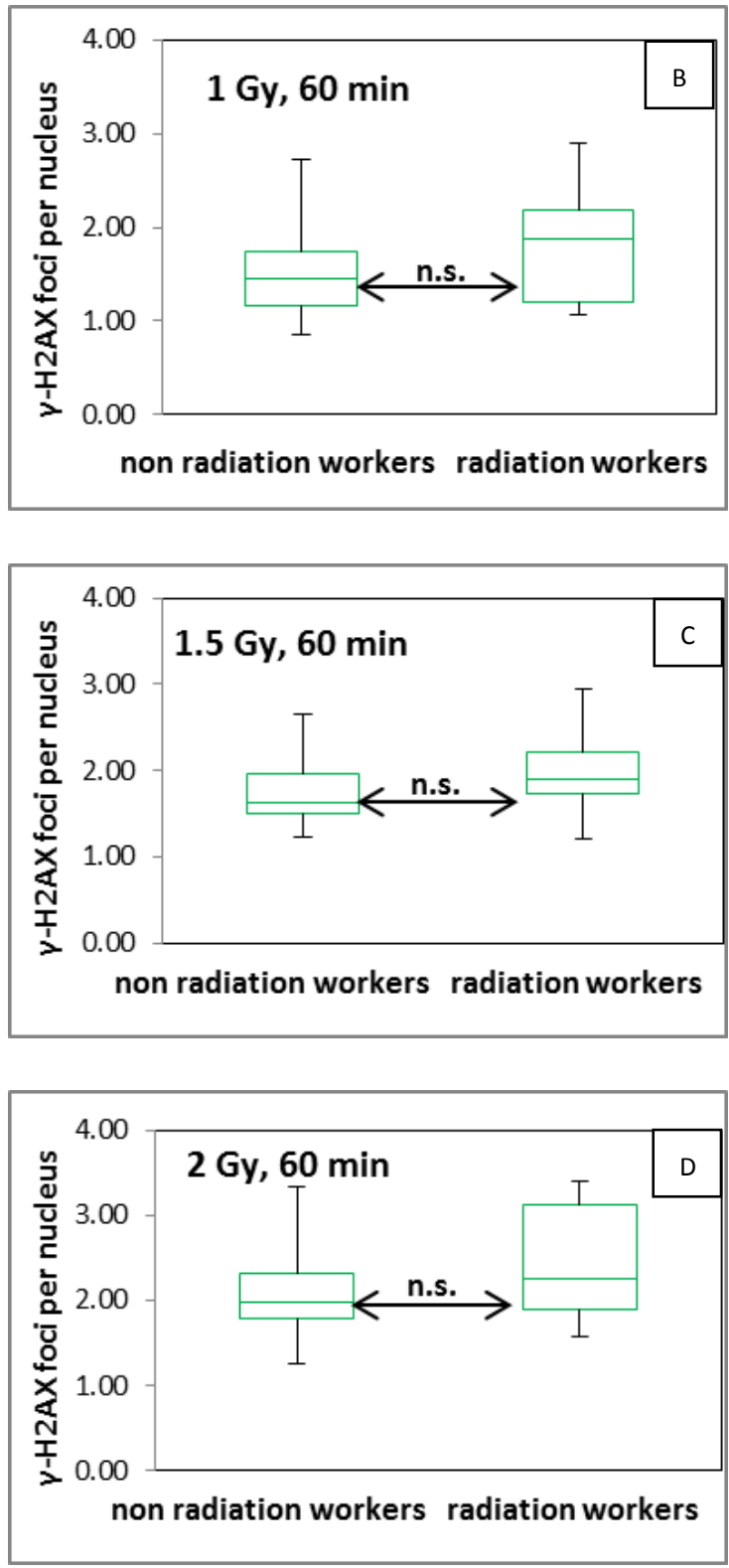

Figure 2. Comparison of foci $\mathrm{Y}-\mathrm{H} 2 \mathrm{AX}$ in radiation workers with doses (A) 0 Gy, (B) 1 Gy, (C) 1.5 Gy, and (D) 2 Gy. 


\section{DISCUSSION}

In this study, PBMCs were isolated from non-radiation workers and radiation workers to be analyzed for DNA damage using $\mathrm{Y}-\mathrm{H} 2 \mathrm{AX}$ histones. Morphologically, the cells exhibit lymphocytes and $\mathrm{y}-\mathrm{H} 2 \mathrm{AX}$ foci expression. There is no difference in morphological features of PBMCs. In each treatment the image of the nucleus is round, relatively large and slightly forming a hollow on one side. When viewed from the pattern of the distribution, foci $\mathrm{Y}-\mathrm{H} 2 \mathrm{AX}$ was seen to spread more evenly around the nucleus, this is because the ionizing radiation used is ray- $\gamma$ which belongs to the low-LET category that can spread in all directions throughout the cell. Urushibara et al. (13) explains that any radiation beam at a particular wavelength gives rise to 1 lesion from 4 ionization and excitation on low-LET radiation and is associated with the formation of 1 DSB around the foci. It is known that $\mathrm{H} 2 \mathrm{AX}$ histone may experience phosphorylation in non-lethal DSB regions. Foci formation can occur spontaneously in small amounts of metabolic processes. In the study of Mognato et al. (15), $\mathrm{Y}-\mathrm{H} 2 \mathrm{AX}$ foci was faster in DNA repair of about $80-90 \%$ for 24 hours induced by $\gamma$-rays.

Based on the increased dose, H2AX formed about 1-2 foci per nucleus after 1 Gy of radiation. While in the research conducted by Djuzenova et al. (6), normal people produce 2 foci per nucleus after given radiation $0.5 \mathrm{~Gy}$. Other publications mentioned an increase in the number of foci 6 to 10 foci per cell after the irradiation of $1 \mathrm{~Gy}$. The difference in the number of foci per cell is due to the number of cells observed, the time after radiation, the distribution of photon planes (X-rays or $Y$ rays), and the biological behavior of each individual (6).

The data showed that there was no significant difference between control and radiation workers at a dose of 0 Gy (Fig. 2). This can be seen from the $p$ value of 0.807 which assumes that the lymphocyte cells between the control and the radiation workers are in normal condition. The mean $\mathrm{Y}-\mathrm{H} 2 \mathrm{AX}$ foci in normal individuals obtained per cell is $0.34 \pm 0.09$ with a range of 0.22 to 0.48 . While in the research conducted by Fleckenstein et al. (16) shows the results of background value of about $0.07-0.08$, which is 6 times lower than the value that has been presented.

Results of statistical analysis on all three doses were not significantly different. The data showed that there was no significant difference between non-radiation workers and radiation workers at doses of $1 \mathrm{~Gy}$ to $2 \mathrm{~Gy}$ (Fig. 2). This can be seen from the value of $p>0.05$ which gives the assumption that between non-radiation workers and radiation workers have the same level of risk of DSBs damage after irradiation. In a study by Cholpon et al., a comparison of the number of foci between normal and abnormal cells was significantly different $(p<0.05)$ after 2 Gy exposure. This shows that in abnormal cells, when given 2 Gy irradiation treatment, it will show the expression of histon $\mathrm{H} 2 \mathrm{AX}$ higher than normal cells (6).

\section{CONCLUSION}

Based on the results of this research, $\mathrm{Y}-\mathrm{H} 2 \mathrm{AX}$ foci in PBMCs is still within normal limits between controls and radiation workers.

\section{ACKNOWLEDGMENT}

The authors would like to thanks Dr. dr. Ramadhan, Sp.B(K)Onk. in Department of Surgical Oncology (Dharmais Cancer Hospital), Dr. dr. Dewi Syafriyetti Soeis, Sp.Rad(K) OnkRad. in Department of Radiotherapy (Dharmais Cancer Hospital), Dr. dr. Agus Susanto Kosasih, Sp.PK. in Department of Clinical Pathology (Dharmais Cancer Hospital), Dr. Drs. Heri Wibowo, M.Biomed. in Department of Immunology (University of Indonesia), Dra. Yanti Lusiyanti, Harry Nugroho Eko Suryantoro, M.Sc., Devita Tetriana, M.Si., Sofiati Purnami, S.ST., and Tur Rahardjo, S.P. in Division of Nuclear Medicine Technique and Radiation Biology (PTKMR - BATAN).

\section{REFERENCES}

1. Mastrangelo G, Fedeli U, Fadda E, Giovanazzi A, Scoizzato L, Saia B. Increased cancer risk among surgeons in an orthopaedic hospital. Occup Med (Lond). 2005 Sep; 5: 498-500.

2. Kase KR. Radiation protection principles of NCRP. Health Phys. 2004 Sep; 87(3): 251-7.

3. Goodhead DT. Initial events in the cellular effects of ionizing radiations: clustered damage in DNA. Int J Rad Biol. 1994 Jan; 65(1): 7-17.

4. Lassmann $M$, Hanscheid H, Gassen D, Biko J, Meineke V, Reiners $C$, et al. In vivo formation of $\gamma-\mathrm{H} 2 \mathrm{AX}$ and 53BP1 DNA repair foci in blood cells after radioiodine therapy of differentiated thyroid cancer. J Nucl Med. 2010 Aug; 51(8): 1318-25.

5. Lehnert, S. Biomolecular action of ionizing radiation. Boca Raton: Taylor and Francis Group LLC; 2007._p

6. Djuzenova CS, Elsner I, Katzer A, Worschech E, Distel LV, Flentje $\mathrm{M}$, et al. Radiosensitivity in breast cancer assessed by the histone $\mathrm{\gamma}-\mathrm{H} 2 \mathrm{AX}$ and 53BP1 foci. Rad Oncol. 2013 Apr 24; 8: 98.

7. Rodrigue $A$, Lafrance $M$, Gauthier $M C$, McDonald $D$, Hendzel M, West SC, et al. Interplay between human DNA repair proteins at a unique double-strand break in vivo. EMBO J. 2006 Jan 11; 25: 222-31.

8. Rogakou EP, Pilch DR, Orr AH, Ivanova VS, Bonner WM. DNA double-stranded breaks induce histone $\mathrm{H} 2 \mathrm{AX}$ phosphorylation on serine 139. J Biol Chem. 1998 Mar 6; 273(10): 5858-68.

9. Redon $C E$, Weyemi $U$, Parekh PR, Huang $D$, Burrel AS, Bonner WM. $\gamma-\mathrm{H} 2 \mathrm{AX}$ and other histone post-translational 
modifications in the clinic. Biochim Biophys Acta. 2012 Jul; 1819(7): 743-56.

10. Nagelkerke A, Van Kuijk SJ, Sweep FC, Nagtegaal ID, Hoogerbrugge N, Martens JW, et al. Constitutive expression of $\mathrm{\gamma}-\mathrm{H} 2 \mathrm{AX}$ has prognostic relevance in triple negative breast cancer. Radiother Oncol. 2011 Oct; 101(1): 39-45.

11. Cha H, Lowe JM, Li H, Lee JS, Belova GI, Bulavin DV, et al. Wip1 directly dephosphorylates gamma-H2AX and attenuates the DNA damage response. Cancer Res. 2010 May 15; 70(10): 4112-22.

12. Kurnia I, Kisnanto T, Lusiyanti Y. Ekspresi $\gamma-\mathrm{H} 2 \mathrm{AX}$ sebagai respon adaptif sel limfosit penduduk desa takandeang daerah dengan radiasi alam tinggi. PSTA BATAN - FMIPA UNS. 2016: 92-6.

13. Urushibara A, Shikazono N, Watanabe R, Fujii K, O'neill P, Yokoya A. DNA damage induced by the direct effect of $\mathrm{He}$ ion particles. Radiation Protection Dosimetry. 2006; 122(1-4): 163-5.

14. Sedelnikova OA, Pilch DR, Redon C, Bonner WM. Histone H2AX in DNA damage and repair. Cancer Biol Ther. 2003 May-Jun; 2(3): 233-5.

15. Mognato M, Grifalconi M, Canova S, Girardi C, Celotti L. The DNA damage response to ionizing radiation in human lymphocytes. In Tech. 2011 Oct 26; 1: 1-28.

16. Fleckenstein J, Kuhne $M$, Seegmuller $K$, Derschang $S$, Melchior $\mathrm{P}, \mathrm{Gräber} S$, et al. The impact of individual in vivo repair of DNA double-strand breaks on oral mucositis in adjuvant radiotherapy of head-and-neck cancer. Int J Radiat Oncol Biol Phys. 2011 Dec 1; 81(5):1465-72. 